OPEN ACCESS

Edited by:

John Quarles,

University of Texas at San Antonio,

USA

Reviewed by:

Kyle John Johnsen,

University of Georgia, USA

Yiorgos L. Chrysanthou,

University of Cyprus, Cyprus

*Correspondence:

Hamid Hrimech

hamid.hrimech@uhp.ac.ma

Specialty section: This article was submitted to

Virtual Environments,

a section of the journal

Frontiers in ICT

Received: 01 June 2016 Accepted: 06 October 2016 Published: 27 October 2016

Citation:

Hrimech H, Beloufa S, Merienne F Boucheix JM, Cauchard F, Vedrenne $J$ and Kemey $A$ (2016) The Effects of the Use of Serious Game in

Eco-Driving Training.

Front. ICT 3:22.

doi: 10.3389/fict.2016.00022

\section{The Effects of the Use of Serious Game in Eco-Driving Training}

\author{
Hamid Hrimech $^{1 *}$, Sabrina Beloufa ${ }^{2,3,4}$, Frederic Merienne ${ }^{2}$, Jean Michel Boucheix ${ }^{3}$, \\ Fabrice Cauchard ${ }^{3}$, Joël Vedrenne ${ }^{2}$ and Andras Kemey 4
}

'Laboratoire d'analyse et modélisation de système pour l'aide à la décision, Ecole Supérieure de Technologie de Berrechid, Université Hassan Premier, Berrechid, Morocco, '²E2I UMR6306, Arts et Métiers, CNRS, Univ. Bourgogne Franche-Comté, HeSam, Institut Image, Chalon-sur-Saône, France, ${ }^{3}$ Laboratoire d'étude des apprentissages et du développement (LEAD) - UMR 5022 du CNRS, Pôle AAFE - Université de Bourgogne, Dijon, France, ${ }^{4}$ RENAULT, Technical Center for Simulation TCRAVA 013, Guyancourt, France

Serious games present a promising approach to training and learning. The player is engaged in a virtual environment for a purpose beyond pure entertainment, all while having fun. In this paper, we investigate the effects of the use of serious game in eco-driving training. An approach has been developed in order to improve players' practical skills in terms of eco-driving. This approach is based on the development of a driving simulation based on a serious game, integrating a multisensorial guidance system with metaphors including visual messages (information on fuel consumption, ideal speed area, gearbox management, etc.) and sounds (spatialized sounds, voice messages, etc.). The results demonstrate that the serious game influences positively the behavior of inexperienced drivers in ecological driving, leading to a significant reduction (up to 10\%) of their $\mathrm{CO}_{2}$ emission. This work brings also some guidelines for the design process. The experiences lead to a determination of the best eco-driving rules allowing a significant reduction of $\mathrm{CO}_{2}$ emission.

Keywords: serious games, driving simulation, eco-driving, interactive guidance metaphors

\section{INTRODUCTION}

The combustion of fossil fuels such as gasoline and diesel to transport people and goods around the world is the second largest source of $\mathrm{CO}_{2}$ emissions. Transporting goods and people produced $23 \%$ of fossil fuel related carbon dioxide emissions in 2013 (IAE, 2015), scientists and industrialists have developed an increasing awareness of environmental issues. The two criteria of fuel consumption and $\mathrm{CO}_{2}$ emission have become an important commercial argument.

However, technology is not the only crucial factor in $\mathrm{CO}_{2}$ emission. Also human factor plays a decisive role. It is obvious that drivers have a significant role to play to reduce their fuel consumption and greenhouse gas emissions by their behavior and driving style. A driver, who is not aware or misinformed about the basic rules of eco-driving, will always have a significant $\mathrm{CO}_{2}$ emission, even if he uses a car with low fuel consumption. In this instance, eco-driving appears as an appropriate solution.

Eco-driving is a training used to improve efficiency and reduce $\mathrm{CO}_{2}$ by improving road users driving style. A number of studies show an average reduction in $\mathrm{CO}_{2}$ emissions of $10-15 \%$ when eco-driving is adopted by the driver (see Table 1). Methods used in eco-driving training have generally been conducted via driving simulators or in the real world. According to Hornung et al. (2000), 
TABLE 1 | Reported fuel savings from eco-driving studies (Abuzo and Muromachi, 2011; Wengraf, 2012).

\begin{tabular}{|c|c|}
\hline Study & Savings in fuel consumption \\
\hline SAFED (2007) & $\begin{array}{l}\text { - } 10 \% \text { reduction in fuel consumption } \\
\text { - } 33 \% \text { reduction in gear changes }\end{array}$ \\
\hline Treatise (2005) & $\begin{array}{l}\text { - } 2.1 \% \text { reduction in fuel consumption } \\
\text { - } 3.5 \% \text { lower level of maintenance } \\
\text { - } 14.2 \% \text { reduction in crash damage }\end{array}$ \\
\hline Boocock and Coyle (2003) & $\begin{array}{l}\text { - All drivers improved their fuel economy by } \\
\text { amounts ranging from } 1.7 \text { to } 34 \% \text {, with } \\
\text { an average improvement of } 13.4 \%\end{array}$ \\
\hline Holcim (2005) & $\begin{array}{l}\text { - } \quad \text { Fuel consumption during training } 8.5 \% \\
\text { - } 5.6 \% \text { after } 7 \text { months }\end{array}$ \\
\hline af Wåhlberg (2007) & $\begin{array}{l}\text { - Fuel consumption during training was } \\
\text { strong } \\
\text { - } 2 \% \text { after } 12 \text { months }\end{array}$ \\
\hline Barth and Boriboonsomsin (2009) & - Between 10 and 20\% \\
\hline Beusen et al. (2009) & - From $12 \%$ savings to a $3 \%$ worsening \\
\hline Rowson and Young (2011) & - $20 \%$ (peak savings of $45 \%$ ) \\
\hline Greene (1985) & - $10 \%$ or more \\
\hline Mele (2008) & - $35 \%$ reduction in fuel consumption \\
\hline Beusen and Denys (2008) & - From $7.3 \%$ savings to $1.7 \%$ worsening \\
\hline Onoda (2009) & $\begin{array}{l}\text { - Between } 5 \text { and } 15 \% \text { reduction in fuel } \\
\text { consumption }\end{array}$ \\
\hline Taniguchi et al. (2006) & - $20 \%$ reduction in fuel consumption \\
\hline Driving Standards Agency, UK & - $8.5 \%$ reduction in fuel consumption \\
\hline Dutch Consumer Organisation & - $7 \%$ reduction in fuel consumption \\
\hline Walden (2008) & - $25 \%$ reduction in fuel consumption \\
\hline Azzi et al. (2011) & - $5-7 \%$ of total polluting emissions \\
\hline Kolman (2009) & - $30 \%$ reduction in fuel consumption \\
\hline Barkenbus (2010) & - $10 \%$ reduction in fuel consumption \\
\hline Barth and Boriboonsomsin (2009) & $\begin{array}{l}\text { - Between } 10 \text { and } 20 \% \text { reduction in fuel } \\
\text { consumption }\end{array}$ \\
\hline Hitchings and Ward (2010) & - $18 \%$ reduction in fuel consumption \\
\hline Barbé et al. (2007) & - $16 \%$ reduction in fuel consumption \\
\hline $\begin{array}{l}\text { Evans (1979),.Hooker (1988); De } \\
\text { Vlieger and Kretzschmar (2000) }\end{array}$ & $\begin{array}{l}\text { - Between } 20 \text { and } 40 \% \text { reduction in fuel } \\
\text { consumption }\end{array}$ \\
\hline $\begin{array}{l}\text { Hornung et al. (2000); Zarkadoula } \\
\text { et al. (2007) }\end{array}$ & - $10-20 \%$ reduction in fuel consumption \\
\hline $\begin{array}{l}\text { Ukita and Shirota (2003); } \\
\text { Miyasaka et al. (2005); } \\
\text { Katayama and Taniguchi (2005) }\end{array}$ & - $25 \%$ reduction in fuel consumption \\
\hline
\end{tabular}

there are no significant differences between the two approaches. However, the traditional training methods do not allow:

- To check if eco-driving rules are properly applied.

- To say which are the eco-driving rules the best integrated by the drivers.

The work presented in this paper aims at proposing an ecological serious-games-based approach in order to improve drivers' ecological awareness and practical skills. A brief description of our approach of eco-driving learning has been presented and some results were rapidly processed in our previous conference paper (Beloufa et al., 2012). In the present paper, a particular attention will be given to the technical aspects of the study where we are going to emphasize more on the interactive guidance. We also try to evaluate the degree of achievement and integration of the eco-driving rules by the drivers.

\section{VIRTUAL REALITY FOR ECO-DRIVING LEARNING}

\section{Driving Simulation}

Driving simulators are found in various areas of use (such as training, industrial prototyping, behavioral studies) (Slob, 2008). A driving simulator is a system that provides a coherent multi-sensory environment for a driver to perceive and control virtual vehicle movements (Kemeny and Panerai, 2003). The driving simulation offers substantial advantages, which are listed below:

- The visual interface, which presents to the driver the current environment state in synthesized images.

- The sound interface, which is able to reproduce the sound effects.

- The proprioceptive interfaces mechanisms for motor control and posture.

o The haptic interface to restore the efforts, which the driver will be able to feel.

- The kinesthetic interface to make the driver feel the effects of displacement in the virtual scene, accelerations and the vibrations.

These techniques made it possible for the driving simulators to have many advantages compared to real vehicles (De Winter et al., 2012), including

- Controllability, reproducibility, and standardization: the repeatability of the situations and the control of the parameters (behavior of virtual traffic, weather conditions, etc.),

- Ease of data collection: (Measurement of position on the virtual road, distance from other cars, etc.), and

- Possibility of encountering dangerous driving conditions without being physically at risk.

\section{Gameplay for Learning}

Gameplay is a term used to describe the interactive aspects of game design. This includes game mechanisms, rules, choices, facilities, difficulties, and progression in order to achieve a goal. All these parameters play an important role in designing a good video-game. The motivation comes by the fact that the game should keep the player engaged, by giving him some tasks that will be carried out in a short-time, while making the play easy to learn but challenging to master (Prensky, 2002).

The fun component represents an important factor in the training process. According to Michael and Chen (2005) fun is a result rather than an objective. The more the tasks handled are amusing, the more the person will be motivated to perform these tasks in a voluntary way. However, the voluntary factor does not 
present in the case of the serious games. On the other hand, this fact does not preclude that the activity provided could be pleasant or desirable, provided it does not impede the training process (Michael and Chen, 2005).

Different playful ways have been used frequently to transmit the knowledge. Edutainment generally corresponds to educating and entertaining at the same time. The initiatives of this field had a few success because they were seen as annoying (Susi et al., 2007); furthermore, the e-Learning paradigm, which means the remote training through new multimedia technologies, has had a relative failure. In this case, the information is available online but a lack of motivation prevents to complete all exercises.

Serious-games attract a larger audience due to their interactive nature. They are always related to simulation applications. The realistic representation of simulated environments enables more immersion, and consequently more motivation. This immersion facilitates a faster training and better information retention (Michael and Chen, 2005). This potential makes the player more involved than training in a classroom (often perceived as useless and tiresome). All in all, these specifications make serious-games an interesting alternative in several sectors.

\section{Eco-Driving}

Eco-driving is a driving behavior toward the environment. Thus, the drivers will contribute to an important reduction of fuel consumption without compromising the efficient movement. According to Wengraf (2012) «Eco-driving is a set of steps, techniques and behaviors that drivers can employ in preparation of the vehicle before a journey, in planning the journey, in modifying driving style during the journey and in reviewing trip data after the journey, that can, taken together, lead to savings (at times, significant ones) in terms of fuel usage, trip cost, emissions of $\mathrm{CO}_{2}$ and other pollution, and levels of noise from vehicle use. These savings can be realized for relatively low cost compared to other kinds of efforts to reduce the environmental impacts of car use. In addition, trips made with eco-driving techniques can, in many cases, be linked to improved road safety; moreover, the use of such techniques does not increase journey times».

This type of driving presents several advantages (Ecodrive, 2016):

- Safety

- Improve road safety and

- Enhance driving skills.

- Financial

○ Save fuel/money (5-15\% in the length-term),

- Lower vehicle maintenance costs, and

- Reduce costs off accidents.

- Environmental

- Reduce greenhouse gas emissions $\left(\mathrm{CO}_{2}\right)$,

- Local fewer air pollutants, and

- Noise reduction.

- Social

- Responsible more driving,

- Less stress while driving, and

- Higher comfort for drivers and passengers.
The factors that could influence the increase of fuel consumption according to Ericsson (2001) and af Wåhlberg (2007) are:

- The driver's behavior and knowledge: lack of information and no respect of the basic rules of eco-driving increase the energy consumption.

- The technology used by the vehicle: consumption change of a vehicle to another according to the engine technology.

- The road state: traffic state and road infrastructures.

There are several studies that have investigated the effectiveness of eco-driving in $\mathrm{CO}_{2}$ emissions (see Table 1). It is difficult to determine the real benefits of eco-driving because the basic conditions change from one study to another (vehicles, road, mathematical models used). Generally speaking, it can be said that the eco-driving can significantly affect the amount of energy and emissions and the efficient driving can reduce emissions by up to $10 \%$. The fuel consumption from eco-driving is more significant in long distance compared to short or medium distance (Bozicnik and Hanzic, 2009). Many eco-driving programs have been implemented in the last 20 years in several countries (see Table 2).

\section{SCIENTIFIC ISSUES AND METHODOLOGY}

\section{Research Question}

Despite technological advances made in cars' engines and especially in energy consumption, fuel consumption remains a considerable challenge in thermal cars. The adaptation of the existing system seems however difficult. According to Larsson and Ericsson (2009), the use of a resistant accelerator pedal beyond a certain level does not give any significant reduction of consumption. Also, many studies (Regan et al., 2006; SaintPierre and Ehrlich, 2008) show that the use of the Intelligent Speed Adaptation (Ericsson, 2001) does not bring any significant reduction of fuel consumption. Besides, a recent study (Azzi et al., 2011) has shown the effectiveness of visual and haptic assistance in eco-driving.

Many car manufacturers propose Ecological Driving Assistance System (EDAS). These assistance systems are mainly embedded devices aboard the vehicles that collect varied data from the driver's behavior, the road, and/or the other vehicles. These systems use the whole information to analyze the driver's behavior, in order to broadcast some crucial recommendations to foster self-learning in eco-driving. However, the use of these EDAS alone without motivation or sensitization does not provide any significant reduction of fuel consumption. The driving style and the driver behavior remain the important elements to be taken into account in the process of eco-driving (Ericsson, 2001).

In this context and in order to support the eco-driving training process, we have developed an approach that is based on the use of virtual reality and the serious game. The objective is to study the influence of a short training in eco-driving environment.

The scientific issues that are addressed in our approach are described below:

- To validate the effectiveness of a short training;

- To determine the effect of the guidance techniques on the behavior of eco-driving by using serious games; 
TABLE 2 | The main ecodrive country program and initiatives.

\begin{tabular}{|c|c|c|c|}
\hline Country & & Activity or method & Comments \\
\hline \multirow[t]{5}{*}{$\begin{array}{l}\text { European } \\
\text { Union }\end{array}$} & Austria & $\begin{array}{l}\text { - National program } \\
\text { - Competition: EcoTriathlon }\end{array}$ & $\begin{array}{l}\text { Since } 2009 \text {, the EU has mandated the fitting of a Gearshift Indicator for manual } \\
\text { transmission that suggests when to shift up or down in order to optimize fuel } \\
\text { consumption }\end{array}$ \\
\hline & Germany & - Training courses, monitoring, feedback, reward & $\begin{array}{l}\text { Many European countries have implemented eco-driving national or regional eco- } \\
\text { driving programs }\end{array}$ \\
\hline & Greece & $\begin{array}{l}\text { - Campaign: National Ecodriving campaign } \\
\text { through the European project ECODRIVEN } \\
\text { - Competition: Ecodriving marathon }\end{array}$ & \\
\hline & Netherlands & $\begin{array}{l}\text { - National eco-driving program (Het Nieuwe } \\
\text { Rijden, or "The New Driving") }\end{array}$ & $\begin{array}{l}13 \text { EU countries integrate an eco-driving training and/or test to accompany their } \\
\text { standard driver's license test }\end{array}$ \\
\hline & Spain & $\begin{array}{l}\text { - Training: Activation plan 2008-2012 } \\
\text { - Training: Ecodriving training (IDEA) }\end{array}$ & \\
\hline \multicolumn{2}{|l|}{$\begin{array}{l}\text { United } \\
\text { Kingdom }\end{array}$} & $\begin{array}{l}\text { - Training: Smarter Driving Training Programme } \\
\text { - Competition: MPG Marathon }\end{array}$ & $\begin{array}{l}\text { The United Kingdom integrates an eco-driving training and test to accompany their } \\
\text { standard driver's license test } \\
\text { UK's Department for Transport provides advice and assistance to operators of larger } \\
\text { vehicles in the freight industry through its Safe and Efficient Driving (SAFED) standard }\end{array}$ \\
\hline \multicolumn{2}{|l|}{ Australia } & $\begin{array}{l}\text { - Driver training program } \\
\text { - Eco Driver Fleet Efficiency Program }\end{array}$ & $\begin{array}{l}\text { The Eco Driver Fleet Efficiency Program is a driver education and behavior change } \\
\text { program developed by the South East Councils Climate Change Alliance }\end{array}$ \\
\hline \multicolumn{2}{|l|}{ Canada } & $\begin{array}{l}\text { - EcoDriver Program } \\
\text { - EcoENERGY-vehicles program }\end{array}$ & $\begin{array}{l}\text { EcoDriver program was developed as a pilot project to test the viability of ecodriving } \\
\text { messaging for Canadian drivers }\end{array}$ \\
\hline \multicolumn{2}{|l|}{ Japan } & $\begin{array}{l}\text { - National campaign called «e-start» } \\
\text { - Promotion of Eco-driving Management System }\end{array}$ & $\begin{array}{l}\text { Eco-driving has been in place in Japan since } 2003 \\
\text { Ten behaviors have been recommended for fuel-conserving eco-driving called "10 Eco } \\
\text { Drive Tips" }\end{array}$ \\
\hline \multicolumn{2}{|l|}{$\begin{array}{l}\text { New } \\
\text { Zealand }\end{array}$} & $\begin{array}{l}\text { - Safe and Fuel Efficient Driving New Zealand } \\
\text { (SAFED NZ) }\end{array}$ & $\begin{array}{l}\text { SAFED NZ is a driver development course for truck, bus, and coach drivers adapted } \\
\text { from a previous program in the UK }\end{array}$ \\
\hline \multicolumn{2}{|l|}{$\begin{array}{l}\text { South } \\
\text { Korea }\end{array}$} & $\begin{array}{l}\text { - National program } \\
\text { - Eco-driving education center } \\
\text { - fiscal support }\end{array}$ & $\begin{array}{l}\text { Since } 2010 \text {, the government is developing the law and budget for promoting eco- } \\
\text { driving guidance equipment. }\end{array}$ \\
\hline
\end{tabular}

- To quantify the economy observed in terms of $\mathrm{CO}_{2}$ emissions;

- To determine the relative contribution of each rule of eco-driving.

\section{Proposed Methodology}

Although this research is not related to the driving task, but the comprehension of this activity is essential in order to propose some guidance techniques with regard to respecting the multidimensional character of this task.

Driving is a complex activity; the driver must have a good reflex and makes the appropriate decisions in order to interpret one or more situations in an efficient way, which could change or degrade very quickly.

According to Michon (1985), the driving task is organized in three levels:

- The strategic level is the highest level of the hierarchy. The tasks in this level require a cognitive effort. However, the drivers are not subjected to strong temporal constraints (for example, determining destinations and waypoints).

- The tactical level is the middle level in which the drivers decide on the action to be taken within moments. At this point, the cognitive requirements are less important than the strategic level. In return, the activities carried out in this level are operated under a massive time pressure, for instance, the decision of overtaking another vehicle.

- The operational level is the lowest level of the hierarchy: steering, braking, accelerating, and monitoring the vehicle and roadway. The cognitive cost associated with this level is very low, but the temporal constraints are very strong.

The driving activity asks for a very high sensory implication level. The principal senses requested during the driving task are (Gruening et al., 1998; Kemeny and Panerai, 2003):

- The vision,

- The sound,

- The tactile, and

- The vestibular system.

The driving task is a particular task which requires from the drivers an extremely cognitive effort. Taking into account this characteristic in the design stage of eco-driving guidance techniques is essential for avoiding interferences between the messages that are naturally used by the driver during the driving task and the messages that they are possible to use in the guidance techniques. It is important not to overload the driver's cognitive capacity, nor to disturb the driver for ensuring the good comprehension of these techniques. 
TABLE 3 | Description of rules.

\begin{tabular}{|c|c|}
\hline Rule & Description \\
\hline Rule “1” & Pass to the higher gear before 2500 rpm \\
\hline Rule "2" & Drive with upper gear possible \\
\hline Rule “3” & Maintain a constant speed if the road is clear \\
\hline Rule "4" & Look far to anticipate decelerations \\
\hline Rule "5" & $\begin{array}{l}\text { To decelerate, in absence of urgency: } 1 \text {. Close the throttle } \rightarrow 2 \text {. } \\
\text { Gear down } \rightarrow 3 \text {. Brake if necessary }\end{array}$ \\
\hline Rule "6" & Stop engine for more than 30 s stops \\
\hline
\end{tabular}

Thus, it is necessary to propose the guidance techniques in a way of taking into account these following criteria:

- Interactivity,

- Comprehensibility, and

- Low cognitive load.

Thereafter, the guidance techniques will be developed according to cognitive criteria as well as eco-driving criteria. These rules are described in Table 3.

For each rule we propose visual and auditory interactive guidance (see Table 4).

Moreover, an indicator permanently posts the $\mathrm{CO}_{2}$ emission level, and a visual message "increase your speed" appears in the center of the screen in blue at the beginning of the courses, if the player speed is lower than $10 \mathrm{~km} / \mathrm{h}$ at the speed of reference recorded by an expert in eco-driving. The dashboard includes always at least the following elements: an engine RPM, a digital speed meter, a gearbox ratio indicator and a GPS (Figure 1).

\section{HARDWARE AND SOFTWARE ARCHITECTURE}

\section{Hardware Configuration}

The system realized is integrated into $\mathrm{eco}^{2}$ simulator. The hardware architecture is shown in Figure 2.

The $\mathrm{eco}^{2}$ simulator (Figure 3 ) is composed of the following components:

- An immersive visualization with three LCD monitors (32 inch diagonal, 100 degree field of view),

- Equipped cockpit,

- Adjustable seat, steering wheel, seat belt, manual gearshift, clutch, gas, and brake pedal assembly with force feedback,

- Audio speakers located in front and behind the seat,

- Vibrators embedded in the seat, and

- The simulator is powered by a HP Z600 Workstation with Quad-Core Xeon processors and NVIDIA Quadro cards.

\section{Software Architecture}

SCANeR II is a driving simulation system designed by Renault and published by Oktal. The product is based on OpenSceneGraph and is intended for automobile engineering. The main components in SCANeR II are (Oktal, 2016) as follows:

- Models: dynamic vehicle, autonomous traffic, pedestrians, scripting.
TABLE 4 | Guidance suggested for each rules.

\begin{tabular}{|c|c|c|}
\hline Rules & Interactive guidance & Representation \\
\hline Rule 1 & $\begin{array}{l}\text { A green zone inserted in the } \\
\text { engine RPM (This zone flickers } \\
\text { automatically if the driving exceeds } \\
\text { the threshold of } 2500 \text { rpm) }\end{array}$ & \\
\hline Rule 2 & $\begin{array}{l}\text { A blue arrow on the right of the } \\
\text { gearbox ratio indicator (this arrow } \\
\text { flickers automatically if the gearbox } \\
\text { ratio is lower than reference gear } \\
\text { recorded preliminary by an expert } \\
\text { in eco-driving) }\end{array}$ & \\
\hline Rule 3 & $\begin{array}{l}\text { The color of the digital speed } \\
\text { meter change (red) (this guidance } \\
\text { starts if the car exceed the speed } \\
\text { limit) }\end{array}$ & \\
\hline $\begin{array}{l}\text { Rules "4" } \\
\text { and "5" }\end{array}$ & $\begin{array}{l}\text { A sound message: "look far" } \\
\text { then "close the throttle" (these } \\
\text { messages start successively if } \\
\text { the player does not release the } \\
\text { accelerator pedal in the dedicated } \\
\text { sections) }\end{array}$ & Sound message \\
\hline Rule "6" & $\begin{array}{l}\text { A sound message: "stop the } \\
\text { engine" (this message starts if the } \\
\text { player does not shout down the } \\
\text { engine in the dedicated sections) }\end{array}$ & Sound message \\
\hline
\end{tabular}

- Restitutors: visual, sound, dynamic platform.

- Acquisitions: virtual or real pilot, tracking systems, physiological data.

The software is used around the operational processes of driving simulators, structured around five dedicated modes of the graphic interface (Oktal, 2016):

- Terrain mode: road network creator RoadXML allowing the rapid creation of realistic road networks-useable directly in the simulation.

- Vehicle mode: tool for the fine-tuning and study of dynamic models.

- Scenario mode: driving simulator scenario editing tool.

- Simulation mode: simulation supervision tool.

- Analysis mode: detailed graphical analysis tool.

For the development of our guidance techniques, we have used SCANER development kit (SDK) that gives the possibility to enriching the system. We have developed modules and plugins 


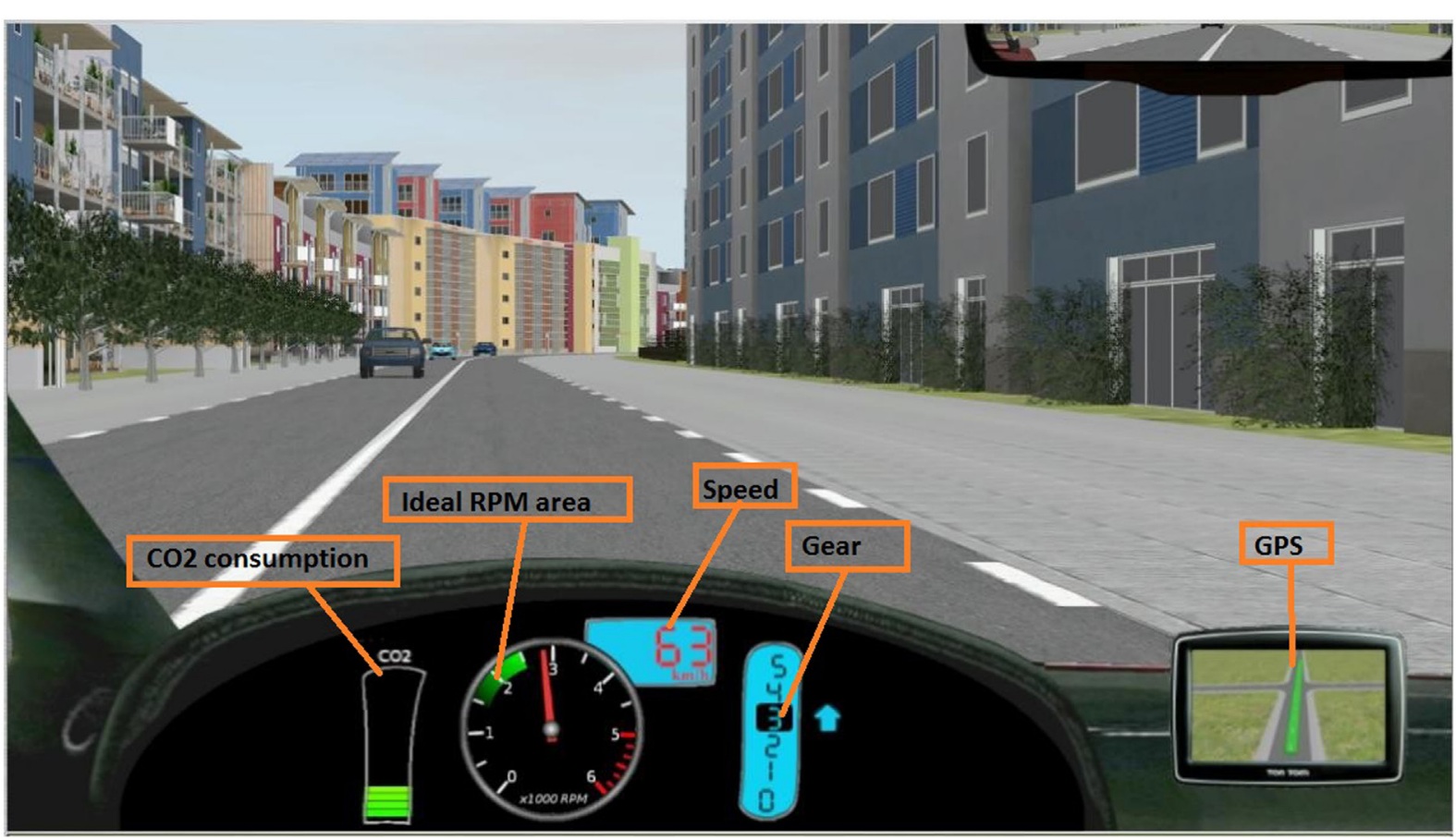

FIGURE 1 | Dashboard with visual guidance.

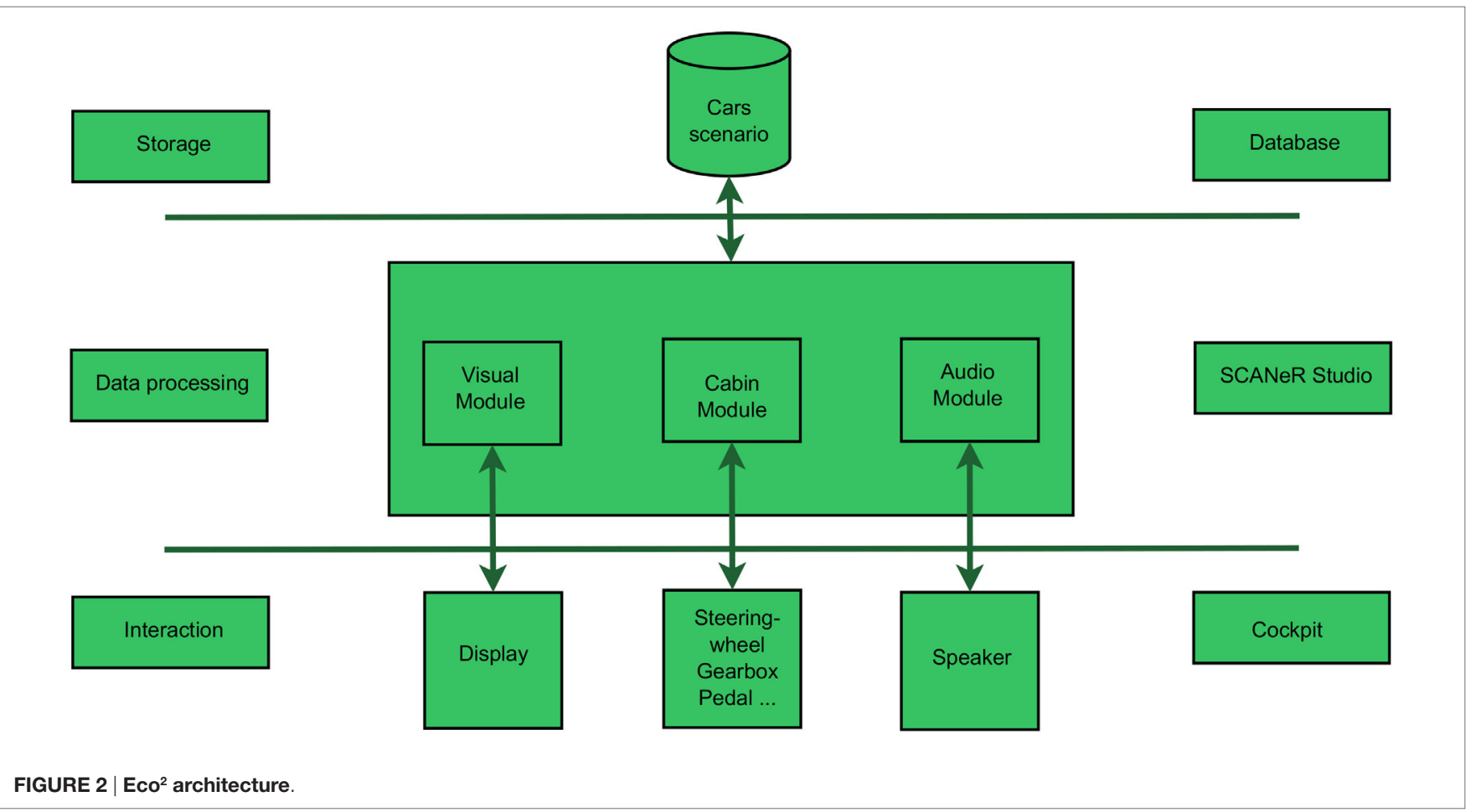

(in $\mathrm{C}++$ language) to integrate our guidance techniques and manage the serious game (Figure 4):

- Administrator: graphical user interface used to manage the serious game (player, scenario, scoring, etc.),
- Datarecorder: module used to recover data during the simulation,

- Eco Sound: module used to integrate the sound guidance,

- Eco Haptics: module used to integrate the vibratory feedback, 


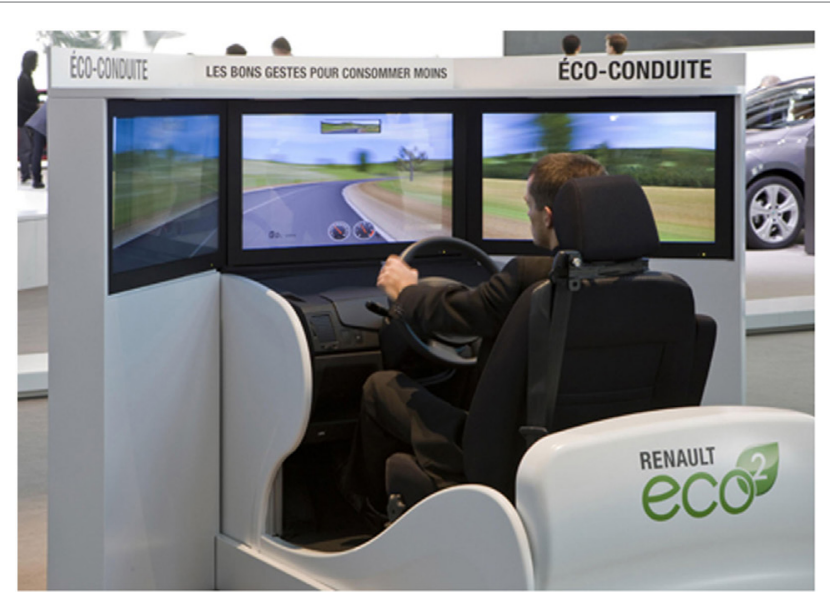

FIGURE 3 | Eco² simulator.
- Scoring modulates: used to ensure player evaluation and scoring,

- Visual: used to integrate visual guidance,

- Scenario: used to edit and configure the simulation scenarios, and

- Genericcab: used to reproduce the simulator cabin (pedals, clutch, buttons, etc.).

\section{THE GAME PLAY «TAXI»}

Players have only a limited time to achieve a particular mission: transport a customer to a meeting within a limited time by minimizing the $\mathrm{CO}_{2}$ emissions. If the player does not arrive to his destination at time, he loses the game. At the end of the course, a debriefing with the detail of its consumption is presented to him/her.

This mode introduces to the players the eco-driving gestures in a progressive way. We have used a series of increasing levels of

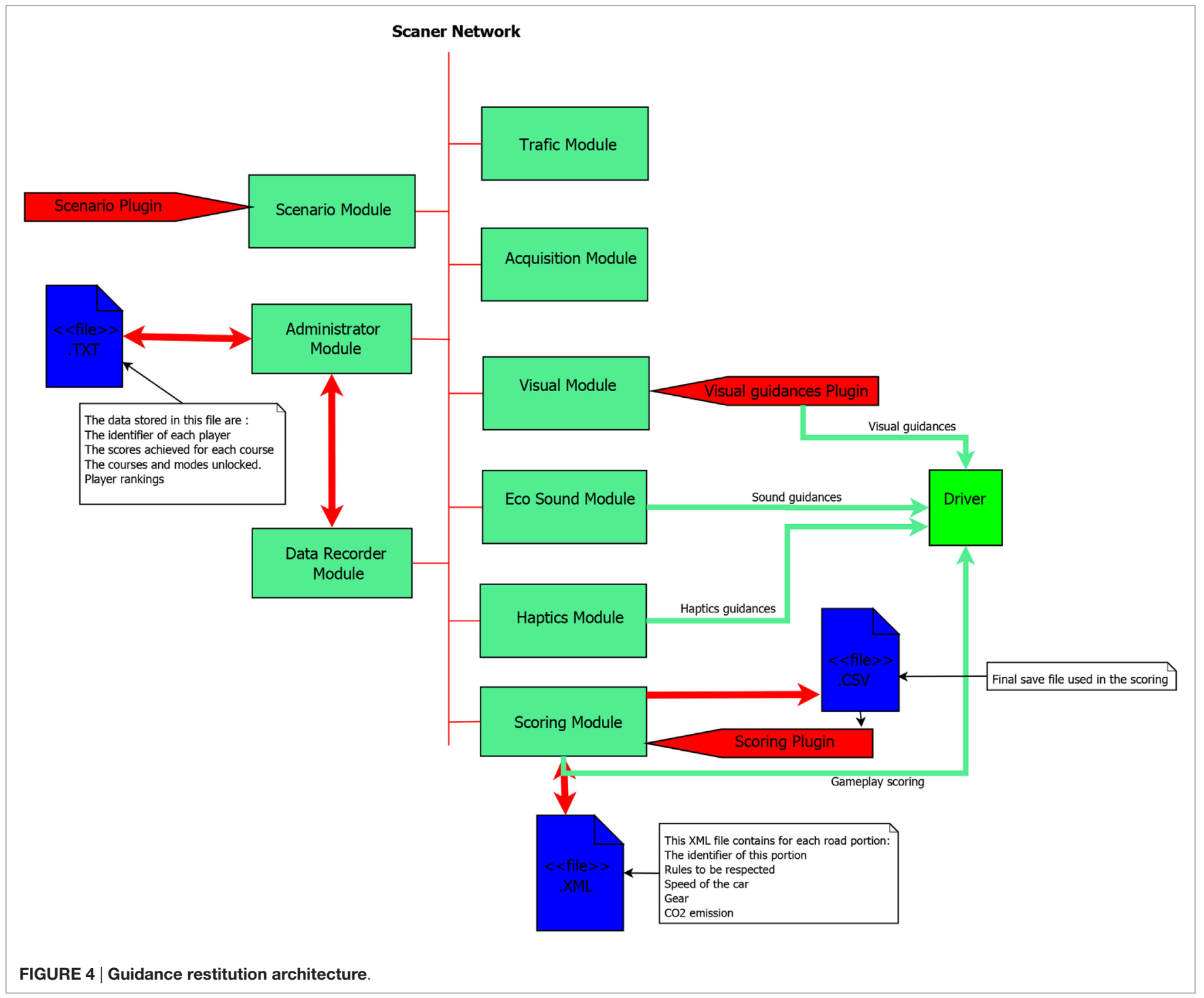


difficulty. To go ahead in the game, the player must reach a specific score calculated from his $\mathrm{CO}_{2}$ emissions. If this score is not reached, the option of retry is given to him. To put into practice each gesture, we have used also some disturbing events on the road like pedestrians or bad drivers. These disturbed events are constant along the course. Each level is preceded by a briefing (which consists of a video) explaining the gestures to be adopted and followed by a debriefing with its total score. As a result, these steps of process enable to evaluate which rules are appropriate and which are not. Finally, in order to improve his/her driving behavior we propose some council.

This game play is proposed to evaluate the players' behavior. It is necessary to recover some data in real-time. These data are:

- The general score corresponding to the $\mathrm{CO}_{2}$ emission,

- Rule 1: average engine speed at the time of the gearbox ratio rising passages,

- Rule 2: average difference between the engaged gearbox ratio and the reference gear recorded by the eco-driving expert,

- Rule 3: SD of the speed variation on the dedicated sections,

- Rules " 4 " and " 5 ": average position of the gas pedal on the dedicated sections, and

- Rule "6": engine stopped or not on the dedicated sections (score 0 or 1 ).

Moreover, a malus system was introduced to evaluate the potential dangerous driving. Also a $\mathrm{CO}_{2}$ emissions penalization has been applied to the total score when driver disobeying traffic laws or control signs (e.g., unsafe passing, tailgating, failing to yield, running red lights or stop signs, etc.).

\section{EXPERIMENTAL STUDIES}

\section{Participants}

A total of 72 drivers took part in the study (3 groups of 24 drivers), 45 men and 27 women, aged between 19 and 55 years (the mean age is 24 years). They have had their driving licenses for at least 1 year ( 36 years to the maximum and 5 years as average) and they drive an average of $9000 \mathrm{~km}$ per year. The participants were randomly assigned to one of the three groups. They were all remunerated for their participation (10 Euros or a USB key). The sample includes students (in majority) and non-students (parents, personnel of the university).

Ethical approval was waived because the study subjects' identifiers were not used and the study protocol was not deemed to represent epidemiological or biomedical research. We made every effort to comply with data protection rules. Study participation was voluntary and will not induce any risk of distress or injury, physical or psychological to the subjects. All participants signed an informed consent form before entering the study. In the cover letter accompanying the questionnaire, it was made clear that participation was on a voluntary basis and that the results would be used for research purposes only.

\section{EXPERIMENTAL CONDITIONS}

During the experiment, three groups were examined (see Table 5):

- G1 "Normal group": with lessons and guidance (24 drivers):

This group benefited from two theoretical trainings lessons as a video in which an expert explains the eco-driving rules and the guidance associated for each rule. Then, the participants performed immediately a drive session in the simulator with the presence of the rules (which are already explained in the theoretical lesson).

- In lesson 1, the expert explains to the drivers rules 1,2 , and 3 with their guidance. This lesson lasted about $1 \mathrm{~m} 43 \mathrm{~s}$ and the following drive phase lasted about $8 \mathrm{~min}$.

- In lesson 2, the expert explains another group of rules " 4 ," "5," and "6," This lesson lasted about $2 \mathrm{~m} 10 \mathrm{~s}$ and the following drive phase lasted about $10 \mathrm{~min}$.

- G2 "Group control 1": with lessons and without guidance (24 drivers)

This group benefited only from the theoretical lessons without the eco-driving guidance in the drive phase.

- G3 "Group control 2": without lesson and guidance (24 drivers)

The group control 2 is a reference group, i.e., they did not receive any instruction and any guidance during the drive phase.

We have considered it unnecessary to add another group without lesson but with guidance because the comprehension of this guidance requires to know their associated rules.

The routes are designed to be coherent with the targeted rules and the evaluation courses, with respect to the requirements of the training courses to allow an evaluation of the rules.

Comparisons carried out between the courses of initial evaluation and final evaluation must respect two important points:

- First, the results should not be biased by the intrinsic characteristics of the courses: for example, a course in heavy traffic shows a high level of $\mathrm{CO}_{2}$ emissions. An obvious solution to this problem is the use of identical courses. But this solution is not scientifically valid.

\begin{tabular}{|c|c|c|c|c|c|c|}
\hline $\begin{array}{l}\text { Phase } \\
\text { Group }\end{array}$ & $\begin{array}{l}\text { Initial evaluation } \\
\text { (duration = } 8 \mathrm{~min} \text { ) }\end{array}$ & $\begin{array}{l}\text { Eco-driving lesson } \\
\text { (duration = } 1 \min 43 \mathrm{~s} \text { ) }\end{array}$ & $\begin{array}{l}\text { Drive } \mathbf{N}^{\circ} .1 \\
\text { (duration = } 8 \mathrm{~min} \text { ) }\end{array}$ & $\begin{array}{l}\text { Eco-driving lesson } \\
\text { (duration = } 2 \min 10 \mathrm{~s} \text { ) }\end{array}$ & $\begin{array}{l}\text { Drive } \mathrm{N}^{\circ} .2 \\
\text { (duration = } 10 \mathrm{~min} \text { ) }\end{array}$ & $\begin{array}{l}\text { Final evaluation } \\
\text { (duration }=8 \mathrm{~min} \text { ) }\end{array}$ \\
\hline G1 & Yes & Yes & Yes & Yes & Yes & Yes \\
\hline G2 & Yes & Yes & Yes but without guidance & Yes & Yes but without guidance & Yes \\
\hline G3 & Yes & No & Yes but without guidance & No & Yes but without guidance & Yes \\
\hline
\end{tabular}


- Second, the familiarity with the course; a familiar course for example makes it possible to anticipate more easily, which has an effect on the $\mathrm{CO}_{2}$ emissions.

A solution to solve the problem partially is to build courses which are as similar as possible (same distance, same turns number, same stops number, etc.). A counterbalancing system is used: for half of the participants on each experimental group, courses used for the initial evaluation and the final evaluation were inverted (Figure 5). This system enabled us to prevent results skewing (effect of the intrinsic differences of the courses and effect familiarity with the course).

\section{RESULTS AND DISCUSSION}

The primary goal of this study is to validate the effectiveness of a short training in eco-driving. To be able to validate the effectiveness of this training it is necessary that the level of $\mathrm{CO}_{2}$ emission observed in the final course is lower than the level of $\mathrm{CO}_{2}$ emission in the initial evaluation.

\section{$\mathrm{CO}_{2}$ Emission}

The analysis performed on the $\mathrm{CO}_{2}$ emission with an ANOVA. We noted a significant reduction in terms of $\mathrm{CO}_{2}$ emission between the initial course and the final course (Figure 6), $F(1,69)=30.7$, $p<0.0001$. The interaction between the factor groups and the factor course (Scenario $\times$ Group) revealed a reliable interaction, $F(3,69)=8.54, p<0.001$.

Post hoc testing (initial vs. final), reveals a:

- Significant difference (reduction) at the group with lesson and guidance $[F(1,69)=32.20, p<0.0001]$.

- Significant difference at the group with lesson and without guidance $[F(1,69)=15.66, p<0.001]$.

- No significant difference was found in the third group $[F(1,69)<1, p=0.98]$.

\begin{tabular}{|c|c|c|c|c|}
\hline Group & $F$ & df & $p$ & $\begin{array}{l}\text { Post hoc } \\
\text { comparisons }\end{array}$ \\
\hline $\begin{array}{l}\text { G1 - with lesson and } \\
\text { guidance }\end{array}$ & 32.20 & 1 & $p<0.0001$ & $\begin{array}{c}\text { Final } \mathrm{CO}_{2} \\
\text { emission }<\text { initial } \\
\mathrm{CO}_{2} \text { emission }\end{array}$ \\
\hline $\begin{array}{l}\text { G2 - with lesson and } \\
\text { without guidance }\end{array}$ & 15.66 & 1 & $p<0.001$ & $\begin{array}{c}\text { Final } \mathrm{CO}_{2} \\
\text { emission }<\text { initial } \\
\mathrm{CO}_{2} \text { emission }\end{array}$ \\
\hline $\begin{array}{l}\text { G3 - without lesson } \\
\text { and without guidance }\end{array}$ & $<1$ & 1 & $p=0.98$ & $\begin{array}{l}\text { No significant } \\
\text { difference }\end{array}$ \\
\hline
\end{tabular}

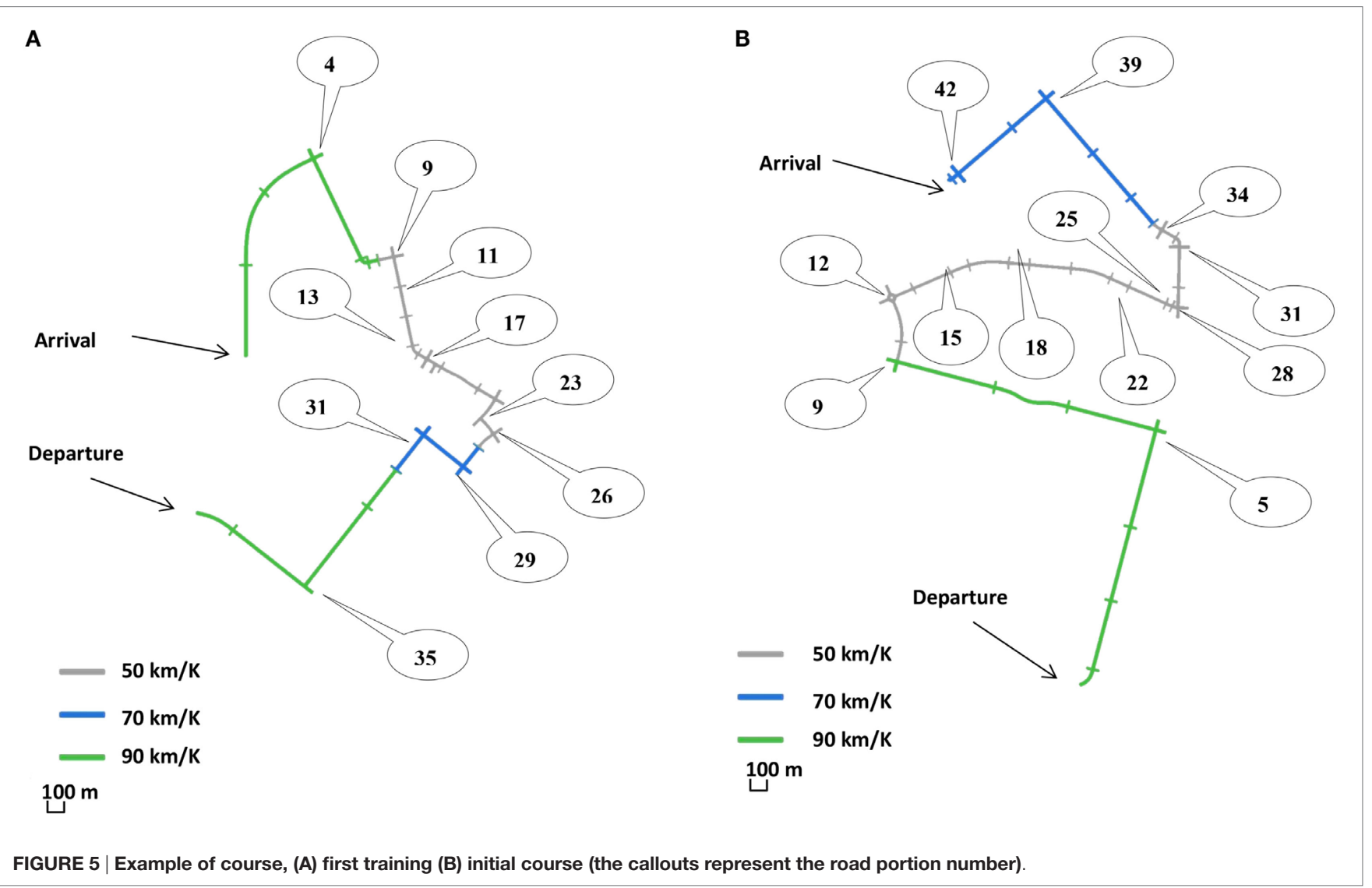




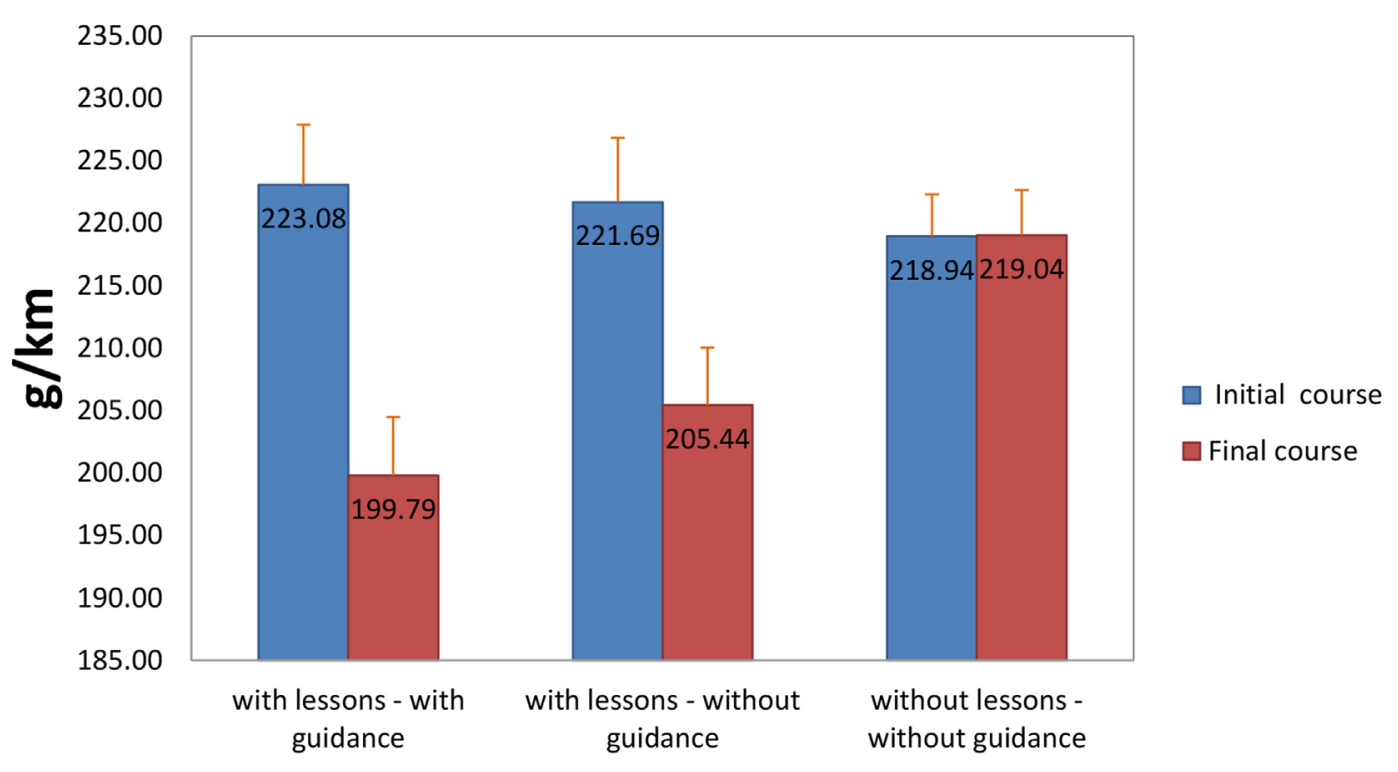

Experimental group

FIGURE 6 | Mean and SD of $\mathrm{CO}_{2}$ emissions for initial (blue) and final (red) courses in grams per kilometer.

Post hoc testing (G1 vs. G2 vs. G3), reveals a:

- significant difference in $\mathrm{CO}_{2}$ emission on the final course $F(2,69)=5.21, p=0.007$ and

- no significant difference was found in $\mathrm{CO}_{2}$ emission on the initial course $F(2,69)=0.21, p=0.80$.

\section{Game Scores}

The comparisons of the scores obtained between the "initial" and "final courses" show that all the rules are generally assimilated, except for the rule 2; the players did not really use the highest gear (see Table 6).

Detailed statistical analyses (linear regression) allow determining the relative contribution for each rule. Two important conclusions can be stated:

- Rules 4 and 5 are the rules that seem to contribute more to the economy realized in terms of $\mathrm{CO}_{2}$.

- The contribution of all the other rules seems to be low.

\section{Discussion}

\section{$\mathrm{CO}_{2}$ Emission}

The results showed a significant decrease of $10 \%$ in $\mathrm{CO}_{2}$ emissions in G1, and of $7 \%$ in G2. This indicates that interactive guidance systems help player to integrate focused eco-driving rules. In G3, no decrease is noticed, which indicates that differences noticed are indeed due to integration of eco-driving rules.

\section{Relative Contribution for Each Rule}

Some observations can be made to try to clarify these results, particularly about rule 1 . The eco-driving rules used in our serious
TABLE 6 | Comparisons of the scores obtained between the "initial" and "final courses" for the G1 "Normal group."

\begin{tabular}{lcc}
\hline Rule & Initial course & Final course \\
\hline Rule 1 (mean engine speed) & $2733 \mathrm{rpm}$ & $2288 \mathrm{rpm}$ \\
Rule 2 (gear ratio difference) & 1.78 & 1.83 \\
Rule 3 (speed SD) & $5.11 \mathrm{~km} / \mathrm{h}$ & $3.84 \mathrm{~km} / \mathrm{h}$ \\
Rules "4" and "5" (anticipation - percentage) & 21 & 14 \\
Rule "6" (stop engine - percentage) & 0 & 75 \\
\hline
\end{tabular}

game are selected and formulated to be easily understood, memorable and applicable. Consequently, they necessarily include some simplifications. "Rule 1: pass to the higher gearbox ratio before $2500 \mathrm{rpm}$," is a simplified version of the following original rule: "To pass a high gearbox ratio with approximately $2000 \mathrm{rpm}$ in diesel and $2400 \mathrm{rpm}$ in gasoline." The car used in the training is a gasoline car. However, in the final course majority of the players change gear: between 1800 and $2200 \mathrm{rpm}$ (for example, more than third of the players of group "Normal"). For these players, rule 1 would be counterproductive.

\section{CONCLUSION}

In this paper, we have showed the results of an experimental study which tried to validate a new approach allowing the use of serious game to help the drivers to adopt an ecological driving in order to reduce the $\mathrm{CO}_{2}$ emissions.

The results obtained show a significant reduction in $\mathrm{CO}_{2}$ emissions level:

- $10 \%$ for the Normal group (with lessons and with guidance).

- We observed also a low reduction (7\%) in the group with lessons and without guidance. 
This shows that interactive guidance helps the driver to integrate the eco-driving rules. Lastly, we do not observe any significant difference for the group without lessons and without guidance, which shows that the differences obtained in the other groups are due to the integration of the eco-driving rules (and not to a possible familiarity with simulator).

\section{REFERENCES}

Abuzo, A. A., and Muromachi, Y. (2011). The effect of ecodrive program on driving behavior and fuel economy of passenger cars in Tokyo. J. East. Asia Soc. Transp. Stud. 9, 858-871. doi:10.11175/easts.9.858

af Wåhlberg, A. E. (2007). Long-term effects of training in economical driving: fuel consumption, accidents, driver acceleration behavior and technical feedback. Int. J. Ind. Ergon. 37, 333-343. doi:10.1016/j.ergon.2006.12.003

Azzi, S., Reymond, G., Mérienne, F., and Kemeny, A. (2011). Eco-driving performance assessment with in-car visual and haptic feedback assistance. J. Comput. Inform. Sci. Eng. 11, 041005-041005. doi:10.1115/1.3622753

Barbé, J., Boy, G., and Sans, M. (2007). GERICO: a human centred eco-driving system. IFAC Proc. 40, 292-297. doi:10.3182/20070904-3-KR-2922.00051

Barkenbus, J. N. (2010). Eco-driving: an overlooked climate change initiative. Energy Policy 38, 762-769. doi:10.1016/j.enpol.2009.10.021

Barth, M., and Boriboonsomsin, K. (2009). Energy and emissions impacts of a freeway-based dynamic eco-driving system. Transport Res. D-Tr. E. 14, 400-410. doi:10.1016/j.trd.2009.01.004

Beloufa, S., Cauchard, F., Benjamin, V., Vedrenne, J., Boucheix, J.-M., Kemeny, A., et al. (2012). "Enhanced game mode for eco-driving simulator," in Driving Simulation Conference (Paris, France).

Beusen, B., Broekx, S., Denys, T., Beckx, C., Degraeuwe, B., Gijsbers, M., et al. (2009). Sing on-board logging devices to study the longer-term impact of an eco-driving course. Transp. Res. D Transp. Environ. 14, 514-520. doi:10.1016/ j.trd.2009.05.009

Beusen, B., and Denys, T. (2008). Long-term effect of eco-driving education on fuel consumption using an on-board logging device, URBAN TRANSPORT XIV - urban transport and the environment in the 21st Century. WIT Trans. Built Environ. 101, 395-403. doi:10.2495/UT080391

Boocock, J. R., and Coyle, M. (2003). Report on the Development of the Safe and Fuel Efficient Driving Standard (SAFED). West Yorkshire, England: University of Huddersfield: Department of Transport and Logistics.

Bozicnik, S., and Hanzic, K. (2009). Soft measures for sustainable road transport. Baltic Trans. J. 50-51.

De Vlieger, I., and Kretzschmar, J. (2000). Environmental effects of driving behavior and congestion related to passenger cars. Atmos. Environ. 34, 4649-4655. doi:10.1016/S1352-2310(00)00217-X

De Winter, J., Van Leuween, P., and Happee, P. (2012). "Advantages and disadvantages of driving simulators: a discussion," in Proceedings of Measuring Behavior (Citeseer), 47-50. Available at: http://citeseerx.ist.psu.edu/viewdoc/ download?doi=10.1.1.388.1603\&rep=rep1\&type $=$ pdf $\#$ page $=47$

Ecodrive. (2016). Ecodrive. Accessed February 24.

Ericsson, E. (2001). Independent driving pattern factors and their influence on fuel-use and exhaust emission factors. Transp. Res. D Trans. Environ. 6, 325-345. doi:10.1016/S1361-9209(01)00003-7

Evans, L. (1979). Driver behaviour effects on fuel consumption in urban driving. Hum. Factors 21, 389-398.

Greene, D. L. (1986). Driver Energy Conservation Awareness Training: Review \& Recommendations for a National Program (ORNL/TM-9897). Available at: http://www.osti.gov/scitech/servlets/purl/5732393

Gruening, J., Bernard, J., Clover, C., and Hoffmeister, K. (1998). "Driving simulation." in SAE Technical Paper Series. SAE International.

Hitchings, M. A., and Ward, T. (2010). CERA week: transportation/fuel trends and beyond. Global Refin. Fuels Today 2, 10.

Holcim. (2005). "Diesel club - one possible measure - aim to reduce fuel consumption and $\mathrm{CO}_{2}$ emissions by 5\%," in Presentation to a Logistics Forum (Antwerp).

Hooker, J. N. (1988). Optimal driving for single-vehicle fuel economy. Transp. Res. 22, 183-201. doi:10.1016/0191-2607(88)90036-2

\section{AUTHOR CONTRIBUTIONS}

HH, FM, SB, JB, FC, and AK: developed the concept. HH, FM, $\mathrm{JV}$, and AK: technical support and developed the guidance techniques. SB, JB, and FC: designed and performed experiments. SB, JB, FC, HH, and FM: analyzed the data. HH and FM: wrote the paper.

Hornung, D., Stiefel, A., Stampfli, M., and von Hebenstreit, B. (2000). "Evaluation of the eco-drive courses," in Response to a Commission from the Federal Office of Energy (German) (Bern). (BBL No. 905.527 d).

IAE. (2015). $\mathrm{CO}_{2}$ Emissions from Fuel Combustion Highlights, 2015 Edn. Paris: International Energy Agency. Available at: https:/www.iea.org/publications/ freepublications/publication/CO2EmissionsFromFuelCombustionHigh lights2015.pdf

Katayama, H., and Taniguchi, M. (2005). A study on practical training system for energy conservational drives. Proc. Soc. Automot. Eng. Japan 20, 80-85. doi:10.4271/2005-08-0383

Kemeny, A., and Panerai, F. (2003). Evaluating perception in driving simulation experiments. Trends Cogn. Sci. 7, 31-37. doi:10.1016/ S1364-6613(02)00011-6

Kolman, D. A. (2009). Eco-driving: simple techniques for operational savings. Refrigerated Transporter 22-23. Available at: http://refrigeratedtransporter. com/vehicles/eco-driving-simple-techniques-operational-savings

Larsson, H., and Ericsson, E. (2009). The effects of an acceleration advisory tool in vehicles for reduced fuel consumption and emissions. Transp. Res. D Transp. Environ. 14, 141-146. doi:10.1016/j.trd.2008.11.004

Mele, J. (2008). Eco-Driving Tips Offer Fuel Savings. Available at: http://Fleetowner. com

Michael, D. R., and Chen, S. L. (2005). Serious Games: Games That Educate, Train, and Inform. Boston: Thomson Course Technology. Available at: http://trove.nla. gov.au/work/20014497

Michon, J. A. (1985). "A critical view of driver behavior models: what do we know, what should we do?" in Human Behavior and Traffic Safety, eds L.Evans and R. C.Schwing (US: Springer), 485-524. Available at: http://link.springer.com/ chapter/10.1007/978-1-4613-2173-6_19

Miyasaka, T., Taniguchi, M., and Sambuichi, H. (2005). "Potentiality of effects by fuel conservation driving in automatic transmission car," in Society of Automotive Engineers of Japan (JSAE), 13-16.

Oktal. (2016). Oktal. Available at: http://www.oktal.fr/en/automotive/range-ofsimulators/software

Onoda, T. (2009). IEA policies - G8 recommendations and an afterwards. Energy Policy 37, 3822-3831. doi:10.1016/j.enpol.2009.07.021

Prensky, M. (2002). The motivation of gameplay: the real twenty-first century learning revolution. Horiz. Strategic Plann. Resour. Educ. Prof. 10, 5-11. doi:10.1108/10748120210431349

Regan, M. A., Triggs, T. J., Young, K. L., Tomasevic, N., Mitsopoulos, E., Stephan, K., et al. (2006). On-Road Evaluation of Intelligent Speed Adaptation, Following Distance Warning and Seatbelt Reminder Systems: Final Results of the TAC SafeCar Project. Available at: http://trid.trb.org/view.aspx?id= 805773

Rowson, J., and Young, J. (2011). Cabbies Costs and Climate Change, an Engaged Approach to Fuel Efficient Behaviour. London: RSA (Royal Society for the encouragement of Arts, Manufactures and Commerce).

SAFED. (2007). Save and Fuel Efficient Driving. Available at: http://www.safed.org.uk

Saint-Pierre, G., and Ehrlich, J. (2008). "Impact of intelligent speed adaptation systems on fuel consumption and driver behaviour," in Proceedings of the 15th ITS World Congress. New York: ITS America, ITS Japan, ERTICO.

Slob, J. J. (2008). State-of-the-Art Driving Simulators, a Literature Survey. DCT Report. 107. Eindhoven University of Technology.

Susi, T., Johannesson, M., and Backlund, P. (2007). Serious Games: An Overview. Institutionen för kommunikation och information.

Taniguchi, M., Kasai, J., and Sambuichi, H. (2006). "A study on the fuel consumption for driving at vehicle starting under energy saving drives," in Proceedings of the Society of Automotive Engineers of Japan (JSAE) (Yokohama), 26. 
Treatise. (2005). Ecodriving: Smart, Efficient Driving Techniques. London: Energy Saving Trust. Available at: www.treatise.eu.com

Ukita, M., and Shirota, H. (2003). Study on the effect of eco-driving by equipping with fuel consumption meter. Proc. Annu. Meet. Environ. Syst. Res. 31, 413-419.

Walden, J. (2008). Economy Drive. Available at: www.accountancyage.com/insider Wengraf, I. (2012). Easy on the Gas - The Effectiveness of Eco-Driving. London: Royal Automobile Club Foundation for Motoring.

Zarkadoula, M., Zoidis, G., and Tritopoulou, E. (2007). Training urban bus drivers to promote smart driving: a note on a Greek eco-driving pilot program. Transp. Res. Board D 12, 449-452. doi:10.1016/j.trd.2007.05.002
Conflict of Interest Statement: The authors declare that the research was conducted in the absence of any commercial or financial relationships that could be construed as a potential conflict of interest.

Copyright $\odot 2016$ Hrimech, Beloufa, Merienne, Boucheix, Cauchard, Vedrenne and Kemey. This is an open-access article distributed under the terms of the Creative Commons Attribution License (CC BY). The use, distribution or reproduction in other forums is permitted, provided the original author(s) or licensor are credited and that the original publication in this journal is cited, in accordance with accepted academic practice. No use, distribution or reproduction is permitted which does not comply with these terms. 